\title{
ICT Availability and Uses among Yemeni University EFL Students
}

\author{
Mohammed Adulkareem A. Alkamel'1, Dr. Santosh S. Chouthaiwale ${ }^{1}$ \\ ${ }^{1}$ Department of English, Indraraj, Arts, Comm. \& Science College/ Dr. BAM University Aurangabad, India \\ Corresponding author: Mohammed Adulkareem A. Alkamel [alkamel2030@gmail.com]
}

\begin{tabular}{llll}
\hline Received: 15.12 .2020 & • Accepted: 23.12.2020 & Published: 29.12.2020
\end{tabular}

\begin{abstract}
This research is an in-depth study to explore the availability and use of Information Communication Technology (ICT) in the departments of English, Yemen. This study aimed to compare public and private universities of Yemen in using ICT tools in the process of studying English as a Foreign Language (EFL). Two questions were used to formulate the study questionnaire and to collect data from 240 students from three public universities and 163 students from private universities. The collected data were analyzed using SPSS. The findings showed a disparity in the usages of ICT by students of Public and Private Universities due to a lack of adequate equipment and good infrastructure. However, the findings of the present study also showed that there is no difference in using computers by students of public and private universities in Yemen which highlights that the education system in Yemen seems to be the same in using ICT tools in learning English. In the case of internet connection, it is found that the availability of internet connection is better in public universities than in private universities.
\end{abstract}

Keywords: ICT; Yemeni EFL students; public universities; private universities; ICT availability; ICT uses

\section{Introduction}

The term ICT stands for information and communication technology, and it refers to forms of technology that are used to transmit, process, store, create, display, share, or exchange information by electronic means. This broad definition of ICT includes such technologies as radio, television, video, DVD, telephone (both fixed-line and mobile phones), satellite systems, and computer and network hardware and software, as well as the equipment and services associated with these technologies, such as videoconferencing, e-mail and blogs (Alkamel \& Chouthaiwale, 2018). ICT is considered to be one of the most important basic bocks of building a society.

The use of technology has become a very important part of education, especially that it is used to help and improve the learning and teaching process inside and outside the classroom. However, most developments in all aspects of life are due to technology that left its marks on every sphere of human life. In the era of globalization, the world and the way it communicates have undergone a sea change in the 21 st century. The last century saw a lot of progressive changes brought about in institutions of higher learning through the incorporation of Information and Communication Technology. Since the implementation of the first computer system in the 1960s, different measures and plans have been developed to increase the integration of Information and Communications Technology (ICT) in all educational fields (Karim et al., 2010; Razak, Yassin, \& Maasum, 2020). ICT is defined as the various technological tools and resources that people use to communicate, create and disseminate knowledge, and use or manage information (Blurton, 1999; Sarkar, 2012; Suleiman, Yahya, \& Turker, 2020). These technologies include computers, the Internet, broadcasting technologies (radio 
and television), and telephony". (Kozma \& Anderson, 2002) stated that ICT has become a major player in the curricular activities among learners and teachers. Information and communication technology (ICT) is a force that has changed many aspects of the way we live, and it has been used worldwide to help people in their business, trade, marketing, science, education, and others (Williams \& Sawyer, 2007; Dixit, Stefańska, Musiuk, \& Singh, 2020).

Now, ICT is currently being used in education to assist students to learn more effectively and help teachers to do administrative tasks more efficiently (Haldorai, Murugan, \& Ramu, 2020). ICT also has the potential to become communication tools, such as emails, chat groups, discussion groups, pals' clubs, Zoom, Google Meet, and other tools and systems to conduct activities that require collaboration, interaction, and feedback (Chien, Hwang, \& Jong, 2020; Goh, \& Sigala, 2020). Also, in the context of Yemen, the scene of ICT and educational technologies are still vague since most of the teaching is still traditional (Yassin, Razak, \& Maasum, 2019), and the situation was not encouraging when face-to-face learning was the cornerstone in English Education (Alsobaihai \& Agrawal, 2017). However, the increased dependency on ICT was proved with the spread of COVID19 , so there is a need to investigate the availability of technological facilities and its use to learn English in public and private universities, Yemen.

What distinguishes this study is that it is the first study that casts light on the use of ICT in the department of English in both types of universities in Yemen. Many studies showed the use of ICT in higher education and education in general, but the researcher makes this study because there are many problems in getting benefits from using ICT in learning the four skills of the English language. So, it can be concluded that it is an attempt to show the availability and uses of ICT in the department of English in public and private universities of Yemen. Hence, the present study is an attempt to survey the availability and uses of ICT in the departments of English in public and private universities in Yemen, and it aims to answer the following questions:

1. How often do Yemeni EFL students in public and private universities use computers at home, universities, and other places?

2. To what extent do Yemeni EFL students of private and public universities have access to the Internet?

\section{Literature Review}

Many studies have discussed the use of Information and Communication Technology in EFL contexts. The use of ICT in EFL is considered to be a very important factor that makes the subject more interested. Many studies showed that the use of ICT in education is an important tool to enhance the teaching and learning of English. Saunders and Pincas, (2004), in a study on students' attitudes towards Information Technologies in Teaching and Learning in the UK, found that students highly used emails and the internet to support their studies. The data obtained showed that a high proportion of the students surveyed are using email as a basic form of networked learning. Students also believe that ICT has a significant role in supporting and enhancing their university learning experience and felt that ICT could sometimes be used as an alternative to face-to-face activities. In the same vein, Melor, Maimun, and Chua (2009) stated that ICT is believed to bring many advantages to the students if it is used under the right circumstances. The authors described the use of ICT for learning English, its challenges for students of English, and students' attitude towards the use of ICT in learning English among the urban school students in Kuala Terengganu, Malaysia. The results of the questionnaire showed that students are aware of the benefits of using ICT in learning the language. Students do not spend one to two hours per week using ICT. Thus, there are two main problems faced by the students which are lack of English proficiency and lack of training on ICT. 
According to Raihan, and Lock (2012), the use of technology for meaningful learning raises serious and significant issues as to how best we can educate our students through technological tools. The authors agreed that a Technology-enhanced teaching environment is more effective than a lecture-based class. Teachers should find methods of applying technology as a useful learning instrument for their learners although they have not learned technology and are not able to use it as a computer expert. However, Somekh (2008) stated that ICTs with the help of a pedagogical framework may provide both students and teachers with flexible, engaging, cost-effective, and personalized learning experiences that keep up with the $21^{\text {st }}$-century cognitive skills into the actual learning process. The authors added that technologically-supported educational environments aim at self-regulated and inquisitive, constructivist, knowledge building rather than knowledge accumulation. So, ICTs can play an eminent role in students' cognitive development as long as they are implemented effectively in teaching and learning practices.

E-learning and ICTs induce inquiry-based, self-directed to enhance learner's cognitive skills Sethy (2012). Technology plays a lion role in acquiring effective, knowledge, and structural learning. Also, access to technological means and their careful use exceeds social and cultural inequalities, resulting in improved learning and teaching practices. Alsobaihai and Agrawal (2017) explored the ICT usage among students and the challenges they face. The study aimed at determining the extent of the use of ICT among students in higher education in Yemen. the author formulated a questionnaire of 720 students from public and private universities of Yemen. So, the study found that the ICT access in the different universities sector for both the students in public and private was not well attended to. The biggest challenge still affecting easy access to ICT facilities in the University remains the limited number of ICT resources which even now do not match with the ever-increasing student population. Nevertheless, there was at least something in place to build on even though it is still limited to computer usage in education that has not reached the fast-advancing educational technologies.

\section{Materials and Methods}

\subsection{Research Design}

The research design which is used in the present study is quantitative. It is the roadmap that guides the research to choose the instruments that are suitable to achieve the objectives of the study, based on the research objectives and questions (Creswell, 2014). It is the guide the addresses the topic of the study and guides the researcher to address the phenomenon under investigation through focusing on instruments, data collection, and data analysis. There different research designs and the current study adopted the quantitative design since it helps the researcher to collect data from a large number of participants to get responses regarding ICT availability and uses. This might not be achieved by other designs taking into consideration that the researchers have collected data from different locations and cities in Yemen. Therefore, quantitative design is the most suitable design to achieve the research objectives.

\subsection{Participants}

The sample was distributed through questionnaires among students. The subjects, 403 students, 240 from public universities, and 163 students from private Universities. The respondents of the questionnaires were both male and female. Out of 240 students from public Universities, 100 were males $(41.7 \%)$, and 140 were females $(58.3 \%)$. Thus, the percentage of female students was higher than of males. The explanation of the frequency of gender distribution of respondents from public universities is shown in Table 1 below. 
Table 1. Gender distribution in public Universities

\begin{tabular}{ccccc}
\hline 1. Gender & Frequency & Percent & Valid Percent & Cumulative Percent \\
\hline Male & 100 & 41.7 & 41.7 & 41.7 \\
Female & 140 & 58.3 & 58.3 & 100 \\
Total & 240 & 100 & 100 & \\
\hline
\end{tabular}

In private universities, out of 163 students, 61 were males (37.4\%) and 102 were females (62.6\%). Thus, the number of females was higher than of males. The explanation of the frequency of gender distribution of respondents from private universities is shown in Table 2 below.

Table2. Gender distribution in private universities

\begin{tabular}{ccccc}
\hline Gender & Frequency & Percent & Valid Percent & Cumulative Percent \\
\hline Male & 61 & 37.4 & 37.4 & 37.4 \\
Female & 102 & 62.6 & 62.6 & 100 \\
Total & 163 & 100 & 100 & \\
\hline
\end{tabular}

\subsection{Instrument}

The instrument of the study was developed by the researchers after careful review of past studies. The items were designed according to the situation of Yemen and based on the needs of the study to achieve its objectives. The validity of the survey was ensured as five experts reviewed the survey and their comments were taken into consideration.

\subsection{Data Analysis}

The data of the study were analyzed using the Statistical Package of Social Sciences (SPSS) through descriptive and inferential statistics. The descriptive statistics through means were used to provide an overview of the comparison between dependent variables (home, university, and other places) and the independent variables (public, and private universities). For research question one, MANOVA was also used to test if there are significant differences between the study variables. In terms of research question two, data were analyzed using descriptive statistics (percentages, and frequencies) to highlight the differences among students according to the study variables in terms of the extent of the internet connectivity.

\section{Results}

\section{How often do Yemeni EFL students in public and private universities use computers at home, universities, and other places?}

Students from public and private universities were asked to state their frequency of computer usage. This question seeks to get information about using the computer in various places. The independent variable in this question is the type of university (public and private), and the dependent variables are at home, at university, and in other places. The aim is to find whether public and private universities differ concerning using computers. Each dependent variable was measured using a 5-point Likert-scale ( $1=$ very often, $2=$ often, $3=$ =sometimes, $4=$ rarely, $5=$ never $)$. 
Table 3 and Table 4 show the descriptive statistics of the students. That is, Table 3 shows the number of students who participated in the study from both the public and private universities to highlight the statistics of the independent variables.

Table 3. Between-Subjects Factors

\begin{tabular}{|c|c|c|c|}
\hline \multicolumn{4}{|c|}{ Between-Subjects Factors } \\
\hline \multirow{3}{*}{ University type } & & Value Label & Number \\
\hline & 1 & Public & 240 \\
\hline & 2 & Private & 163 \\
\hline
\end{tabular}

Table 4 shows the descriptive statistics of the students who participated in the study. The table was analyzed based on the dependent variables of home, university, and other places, and it was linked to the independent variables, namely public and private universities. The table shows that the highest mean for both groups (public and private universities) is using the internet in universities with a mean value of 4.23 for students of public universities, 4.01 for students of private universities, and the total mean value of 4.14 for both groups. The second dependent variable is other places with a mean value of 3.81 for students of public universities, a mean value of 3.39 for private universities, and the total mean value of 3.86 for both groups. The third dependent variable is using the internet at home, and the analysis shows that the mean value of this variable is less than the previous two variables. That is, the mean value of students at public universities is 2.93 , the mean value of students at private universities is 2.83 , and the total mean value of the two groups is 2.89 .

Table 4. Descriptive statistics of using computer at various places

\begin{tabular}{ccccc}
\hline $\begin{array}{l}\text { How often do you use a } \\
\text { computer at these places? }\end{array}$ & University type & Mean & Std. Deviation & N \\
\hline At home & Public & 2.93 & 1.411 & 240 \\
& Private & 2.83 & 1.534 & 163 \\
\multirow{4}{*}{ At university } & Total & 2.89 & 1.461 & 403 \\
& Public & 4.23 & 1.158 & 240 \\
\multirow{4}{*}{ At Other places } & Private & 4.01 & 1.329 & 163 \\
& Total & 4.14 & 1.233 & 240 \\
& Public & 3.81 & 1.265 & 163 \\
\hline
\end{tabular}

The comparison between the groups to investigate if there are significant differences is shown in Table 5 below.

Table 5. Tests of Between-Subjects Effects

\begin{tabular}{ccccccc}
\hline Source & $\begin{array}{c}\text { Dependent } \\
\text { Variable }\end{array}$ & $\begin{array}{c}\text { Type III Sum of } \\
\text { Squares }\end{array}$ & Difference & $\begin{array}{c}\text { Mean } \\
\text { Square }\end{array}$ & F & p-value \\
\hline University Type & At home & 0.989 & 1 & 0.989 & 0.463 & 0.497 \\
& At university & 4.567 & 1 & 4.567 & 3.02 & 0.083 \\
& At other places & 1.259 & 1 & 1.259 & 0.677 & 0.411 \\
& At home & 856.986 & 401 & 2.137 & & \\
& At university & 606.371 & 401 & 1.512 & & \\
& At other places & 745.679 & 401 & 1.86 & & \\
\hline
\end{tabular}


From the Test of 'Between Subject Effects' in Table 5, it can be seen that public and private universities do not differ with respect to using computers at home [ $\mathrm{f}(1,401)=0.463, \mathrm{p}=0.497)]$. From the descriptive statistical table, it is reflected that public universities have the mean value of 2.93, and private universities have the mean value of 2.83 .

In the case of the university, from the Test of 'Between Subject Effects' table, it is shown that public and private universities do not differ with respect to using computers at university [ $f(1,401)=3.02$, $\mathrm{p}=0.083)$ ]. Also, Table 5 shows that public universities have the mean value of 4.23 , and private universities have the mean value of 4.01 .

In the case of other places, from the Test of 'Between Subject Effects' table, it can be seen that public and private universities do not differ with respect to using computers at university $[\mathrm{f}(1,401)=$ $0.677, \mathrm{p}=0.411)$ ]. Also, public universities have the mean value of 3.81 , and private universities have the mean value of 3.91 .

\section{To what extent do Yemeni EFL students of private and public universities have access to the Internet?}

Students from public and private universities were asked to tell if they have an internet connection to use. The question aims to get information about the availability of internet connection to use at the university. Table 6, Figure 1, and Figure 2 show the relationship between the type of universities and access to the internet connection.

Table 6. Availability of Internet Connection

\begin{tabular}{lcccc}
\hline & \multicolumn{2}{c}{ Internet connection at the campus } & \\
& & Yes & No & Total \\
\hline University Type & Public & 147 & 93 & 240 \\
& & $61.20 \%$ & $38.80 \%$ & $100.00 \%$ \\
& Private & 57 & 106 & 163 \\
& & $35.00 \%$ & $65.00 \%$ & $100.00 \%$ \\
\hline Total & 204 & 199 & 403 \\
& & $50.60 \%$ & $49.40 \%$ & $100.00 \%$ \\
\hline
\end{tabular}

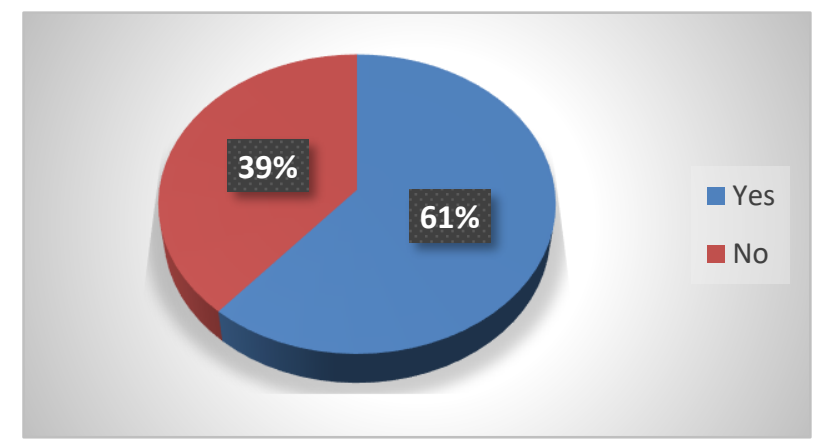

Figure 1. Availability of internet connection in Public Universities

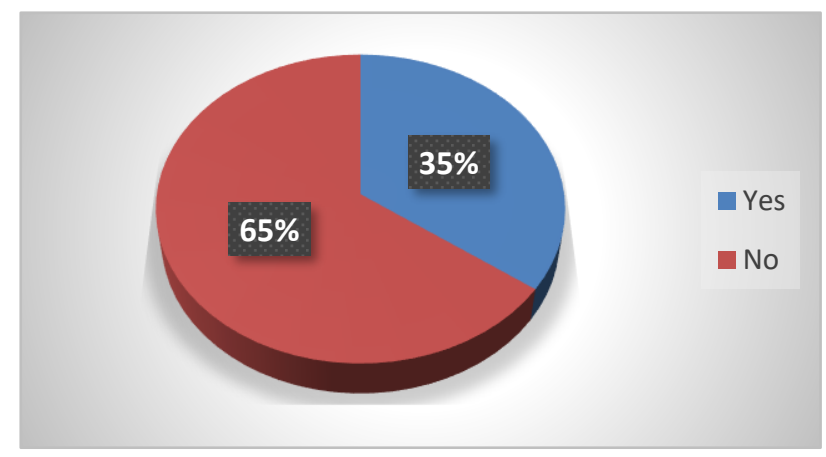

Figure 2. Availability of internet connection in Private Universities 
The above table and figures showed that approximately 147 students $61 \%$ in public universities and 57 students $35 \%$ in private universities have a connection at their campus. This shows the popularity and high usefulness of computers to the student population out of the total selected samples respectively. This also shows that condition of internet connection is better in public universities as compared to private universities.

\section{Discussion}

Many studies investigated the use of ICT in EFL contexts. The results of these studies showed that the use of ICT is very important and beneficial for students as well as teachers. Saunders and Pincas (2004) and Melor et al. (2009) believed that ICT brings many advantages in teaching and learning English. The use of ICT can be used as an alternative to face-to-face activities. The result is that the students do not use ICT for more than one to two hours a week. That is because of the lack of ICT training. On the other hand, this paper showed approximately the same results. The students of public and private universities use the computer for English education less than once a month. A study conducted by Raihan, and Lock (2012) showed that technology-enhanced teaching is more effective than lecture-based class. So, the author concludes that teachers should find methods to apply technology as a teaching tool. Likewise, this paper insists on the use of technology in the teaching and learning process, which is increasing rapidly in the technological age of the $21^{\text {st }}$ century.

The present study is compatible with the study of Somekh (2008) that the use of ICT provides teachers and learners of English with flexible, engaging, cost-effective, and personalized learning experiences. So, ICT plays an essential role in developing the teaching and learning process because learning is can happen in any place, and teachers can make learning more fruitful by incorporating media and attractive features of ICT.

A study conducted by Sethy (2012), showed that ICT can direct students to enhance cognitive skills. However, in this study, the researcher showed that students need qualified teachers to guide them on how they can use ICT in learning English. Therefore, the low utilization of technology in private and public universities might be explained by the less focus on the training lecturers and teachers on how to utilize technology in teaching EFL students.

A study by Alsobaihai and Agrawal (2017) cast the light on the same problem of the present study, which showed that there exist some challenges faced by learners. So, students sometimes use the computer at home, university, and other places, but the use of ICT for improving the English language might be limited since the educational orientation in Yemen is not encouraging the utilization of technology in teaching EFL students. This might be explained by that the use of ICT among students is still a self-direction among learners, who might use materials on the internet to improve the language (Razak, Yassin, \& Maasum, 2020). However, this might lead to another problem related to the skills of the students to get authentic materials. Such an issue might make their use of technology to improve their English language less effective.

The findings of the present study showed that there is no difference in using computers by students of public and private universities in Yemen. This shows that the education system in Yemen seems to be the same in using ICT tools in learning English. In the case of internet connection, it is found that the availability of internet connection is better in public universities than in private universities. However, the use of ICT in Yemeni universities, in general, is still not encouraging, and the spread of COVID-19 supported this view because almost all the universities stopped education and did not use online learning as a solution to keep the students on track of education. 


\section{Conclusion and Implications}

The present study aimed at investigating the availability and uses of ICT among EFL students in the universities of Yemen. It is a comparative study between public and private universities of Yemen. The use of ICT in the Yemeni universities needs to have more focus to reconstruct a good infrastructure. ICT should have more importance in teaching and learning English. This would support students to keep up with modern educational technologies, used in various developed countries. However, from the findings of the present study, it can be concluded that students of both public and private universities should use computers more in learning English. On the other hand, the infrastructure of universities regarding the use of ICT is insufficient in both public and private universities.

Training students, as well as teachers on how to use ICT tools in teaching and learning English, would help in building a good infrastructure that improves the level of the educational system in Yemeni institutions, both public and private. It ensures that the institutions go toward the path that led to the $21^{\text {st }}$-century education system available in the developed countries.

Based on the findings of the present study, some recommendations would improve the use of ICT in the departments of English in public and private universities of Yemen. First, universities should invest more computers for the language labs of English departments as a means of improving the teaching and learning process. So, infrastructures such as printers and projectors should be provided for academic staff and the students to support the process of English language teaching and learning. Second, every classroom should have at least one computer with an internet connection and an LCD projector. Besides, there is a need to provide the English labs with all electronic facilities to enable students of acquiring better knowledge interaction and improve the quality of education. An internet connection can be provided at the campus so that staff, teachers, and students can access and use it for learning purposes. Finally, universities should liberalize the availability of the internet and e-mails in the department of English by establishing an ICT resource center where students can be offered new and varied packages and all versions of the technology.

\section{References}

Alkamel, M. A. A., \& Chouthaiwale, S. S. (2018). The use of ICT tools in english language teaching and learning: a literature review. Journal of English Language and Literature (JOELL), 5(2), 29-33.

Alsobaihai, K. A., \& Agrawal, P. (2016, December). ICT in higher education in the universities of Yemen: Issues and challenges. In 2016 International conference on global trends in signal processing, information computing and communication (ICGTSPICC) (pp. 562-566). IEEE.

Blurton, C. (1999). New directions of ICT-use in education. Retrieved on, 24, 2012.

Chien, S. Y., Hwang, G. J., \& Jong, M. S. Y. (2020). Effects of peer assessment within the context of spherical video-based virtual reality on EFL students' English-Speaking performance and learning perceptions. Computers \& Education, 146, 103751.

Creswell, J. W. (2014). A concise introduction to mixed methods research. SAGE publications.

Dixit, S., Stefańska, A., Musiuk, A., \& Singh, P. (2020). Study of enabling factors affecting the adoption of ICT in the Indian built environment sector. Ain Shams Engineering Journal.

Goh, E., \& Sigala, M. (2020). Integrating Information \& Communication Technologies (ICT) into classroom instruction: teaching tips for hospitality educators from a diffusion of innovation approach. Journal of Teaching in Travel \& Tourism, 20(2), 156-165. 
Haldorai, A., Murugan, S., \& Ramu, A. (2020). Evolution, challenges, and application of intelligent ICT education: An overview. Computer Applications in Engineering Education.

Karim, N. S. A., Nordin, Z. A., Maidin, A. J., \& Ismail, M. S. (2010, June). Electronic land administration system in Malaysia: A proposed review from ICT and legal perspectives. In 2010 International Symposium on Information Technology (Vol. 1, pp. 1-6). IEEE.

Kozma, R. B., \& Anderson, R. E. (2002). Qualitative case studies of innovative pedagogical practices using ICT. Journal of computer assisted learning, 18(4), 387-394.

Melor, M. Y., Maimun, A. L., \& Chua, P. L. (2009). Language learning via ICT: Uses, challenges and issues. WSEAS Transactions on Information Science and Applications, 6(9), 1453-1467.

Raihan, M. A., \& Lock, H. S. (2012). Technology integration for meaningful learning-the constructivist view. Bangladesh Educational Journal, 11(1).

Razak, N. A., Yassin, A. A., \& Maasum, T. N. R. T. M. (2020). Formalizing Informal CALL in Learning English Language Skills. In Enhancements and Limitations to ICT-Based Informal Language Learning: Emerging Research and Opportunities (pp. 161-182). IGI Global.

Saunders, G., \& Pincas, A. (2004). Students attitudes towards information and communication technologies in teaching and learning in the UK. International Journal of Instructional Technology and Distance Learning, 1(8).

Sarkar, S. (2012). The role of information and communication technology (ICT) in higher education for the 21st century. Science, 1(1), 30-41.

Sethy, S. S. (2012). COGNITIVE SKILLS: A Modest Way of Learning through Technology. Turkish Online Journal of Distance Education, 13(3), 260-274.

Somekh, B. (2008). Factors affecting teachers' pedagogical adoption of ICT. In International handbook of information technology in primary and secondary education (pp. 449-460). Springer, Boston, MA.

Suleiman, M. M., Yahya, A. T., \& Tukur, M. (2020). Effective Utilization of ICT Tools in Higher Education. development, 2, 5.

Williams, B. K., \& Sawyer, S. C. (2007). Using information technology: A practical introduction to computers \& communications.

Yassin, A. A., Razak, N. A., \& Maasum, N. R. M. (2019). Investigating the Need for Computer Assisted Cooperative Learning to Improve Reading Skills Among Yemeni University EFL Students: A Needs Analysis Study. International Journal of Virtual and Personal Learning Environments (IJVPLE), 9(2), 15-31. 